\title{
IAMJ
}

INTERNATIONAL

AYURVEDIC

MEDICAL JOURNAL

Review Article

ISSN: 2320-5091

Impact Factor: 6.719

\section{RIGHTS AND DUTIES OF PHYSICIAN ACCORDING TO AYURVEDA AND MODERN PERSPECTIVE}

\author{
Durga Lal Sharma1, Shri Ram Saini \\ ${ }^{1}$ Prof. \& HOD, Agad Tantra Department, SBLD Ayurved Viswabharti Sardarshar, Churu, Rajasthan, India \\ ${ }^{2}$ Assistant Prof., Roga Nidana Evam Vikriti Vigyana Department, SBLD Ayurved Viswabharti Sardarshar, \\ Churu, Rajasthan, India
}

Corresponding Author: drshribams06@gmail.com

https://doi.org/10.46607/iamj3009082021

(Published Online: August 2021)

Open Access

(C) International Ayurvedic Medical Journal, India 2021

Article Received: 19/07//2021 - Peer Reviewed: 01/08/2021 - Accepted for Publication: 02/08/2021

\section{Check for updates}

\begin{abstract}
Ethics is a collection of principles that govern proper behaviour. In Ayurveda, the concept of ethics is strongly related to the concept of Dharma. Many instructions on appropriate medical practice can be found in Ayurveda textbooks. Chatushpada describes the qualities of a good patient and a good physician. The Adhyayana Vidhi clarifies the process of medical education as well as the rules for establishing future practises. Other milestones include Sadvritta and Vaidya Vrutti, which are extensive sets of standards for professional ethical conduct. Ayurvedic Acharyas also instruct physicians on how to communicate with patients. As Ayurveda is the oldest medical science, ethical codes in medicine have existed since the beginning. In the numerous Ayurvedic Samhitas, references to medical ethics were described, including the responsibility of a physician, ideal qualities of a physician, surgeon qualities, medicinal dose (according to nature of individuals) and medicinal dosage for children, as well as specifics of post-mortem and anaesthetic. This paper enlightens the duties of a physician with Ayurvedic and modern perspectives.
\end{abstract}

Keywords: Ayurveda, Duties, Physician 


\section{INTRODUCTION}

For a medical practitioner, ethics is a moral principle. It outlined the mandatory and voluntary responsibilities of a general practitioner. Physician-patient relationships, physician-state relationships, and physician-co-worker relationships are all important. During his or her duties, every registered medical practitioner is required to undertake some medicolegal duties. In the emergency room, they are required to make an injury report in all cases that are not natural. If he fails to perform this responsibility, he may face charges and punishment under several sections of the IPC. ${ }^{1}$ In addition, a male/female attendant for a male patient and a female attendant for a female patient should be present during the inspection of the cases. To prevent being accused of negligence, the next inward doctor must thoroughly analyse the case and treat the patient with a reasonable degree of skill, care, and knowledge. Consent is implied when a patient visits a doctor for treatment. It signifies voluntary agreement, cooperation, or authorization. It is not necessary to obtain written consent. ${ }^{2}$ However, in other instances, written authorization is required. The victim and the accused cannot be interviewed without his or her written agreement in criminal trials, poisoning cases, or rape cases. Different consenting ages: 12 years and up for medical and legal examinations, 16 years and up for sexual intercourse. ${ }^{3}$ The values of a physician, as well as physician responsibilities towards sick and healthy people, were described by Acharya Charaka. Before well testing, a physician will prescribe the medicine, and the dose will be determined based on Kala, Matra, Prakarti, Bala, and other factors. ${ }^{4}$ Before a surgical surgery, Acharya Vrdha Vagbatta describes the anaesthetic and gives the patient pre-operative, operative, and post-operative instructions. ${ }^{5}$ The Sushruta describes the post-mortem procedure for suspected death and death caused by poisons in ancient times. According to Acharya, children require a different dose and medicine manufacturing process than adults. ${ }^{6}$

Aim: To educate physicians/clinicians about their legal obligations when providing medical care or treatment in a clinic or hospital setting.

\section{Materials and Methods}

As study sources for ancient ethical morals, the Charaka Samhita, Sushruta Samhita, Ashtanga Sangrah, and Ashtanga Hridaya books of Ayurveda were used. The accessible literature on modern ethical science was also gathered. These references were compared and critically assessed from both streams of knowledge.

MEDICAL ETHICS: It is concerned with ethical norms for restorative practitioners in their interactions with one another, their patients, and the state. It could be a self-imposed code or behaviour that therapeutic specialists expect. The medical council of India, with the permission of the federal government, enacted the Indian medical council [professional conduct, etiquette, and ethics] regulations, 2002, under the Indian medical council act, $1956 .^{7}$ A physician in Ayurveda is a person who heals patients, is wellversed in the practical elements of the meanings contained intense aphorisms and is well-versed in all facets of life. a. Moral principles that regulate a person's behaviour or the conduct of an activity: $b$. The body of knowledge that deals with moral principles, so physician ethics refers to moral principles or behaviour or the conduct of an activity relevant to a physician during practise.

\section{DUTIES OF GENERAL PHYSICIAN: ${ }^{8}$}

1. A doctor should be proud of his vocation. The primary goal of a medical professional is to benefit humanity.

2. The brilliantly individual who aspires to be a great doctor must constantly strive to improve in the acquisition of the finest qualities of a doctor, to be a genuine supplier of life to individuals.

3. Whoever possesses all these good qualities, knowledge, and so on, deserves the prefix of "good" before "physician," and thus becomes a benefactor of humanity.

4. The physician must maintain a pure character and be modest, sober, patient, and prompt in performing his duties without worry.

The qualities of a physician are described in various chapters in the Charka Samhita, the main text of 
Kaya Chikitsa, but their four main qualities are described in Sutra Sthana $9^{\text {th }}$ chapter, and some more qualities are mentioned in Vimanasthana, as follows: excellence in theoretical knowledge, extensive practical experience. ${ }^{9}$ The physicians should be of high descent, well-versed in scriptures, possessing practical knowledge, expert, clean, skilful, self-controlled, well-equipped, possessing all sense organs (normal), possessing knowledge of constitution and course of action, and be regarded as promoters of vital breath and destroyers of diseases, according to the Charka Samhita. ${ }^{10}$ Other traits of the best physician are listed in the charka Samhita at the end of the 9th chapter of sutra Sthana as follows: learning, rationality, particular knowledge, memory, devotion, and action-one that possess these six qualities, nothing is unattainable for him. Even one of these qualities, learning, wisdom, practical knowledge, experience, accomplishment, and popularity, is sufficient to lend value to the degree of 'Vaidya.' The person who possesses all of the fortunate attributes, such as learning, is deserving of the honourable title of 'Vaidya,' who bestows bliss on all living beings. ${ }^{11}$ The attributes of a surgeon are listed below in the Sushruta Samhita, which is the major text of the Shalyatantra. A physician who is well-versed in the science of medicine and has observed surgical and medical demonstrations, and who himself practises the healing art, and who is clean, courageous, light-handed, fully equipped with medical supplies, surgical instruments, and appliances, and who is intelligent, well-read, and a man of ready resources, and who commands a decent practise, and is furious. ${ }^{12}$

\section{Types of Physician ${ }^{13}$}

In Charka Samhita Sutra 11th chapter three kinds of physicians are mentioned as follows

- Chadmachara physician (fraudulent);

-Siddhasadhita physician (imposters);

-Pranabhisara physician (true physicians).

Those impersonating accomplished physicians and others equipped with physician qualities are referred to as fraudulent physicians. Those who utilise the term "physician" because they have some containers with drugs, models (and charts), worthless discourse, and a phoney appearance are fools and fakes. ${ }^{14}$

Siddhasadhita physicians (imposters) are physicians who practise in the name of famous physicians in terms of wealth, fame, and knowledge, even though they are not identical to them. ${ }^{15}$

Pranabhisara physicians (genuine physicians) are those who are skilled in logical administration, understanding, specific knowledge, and spaces, and who bring happiness and encourage life. ${ }^{16}$

It is also stated that if the other three props are missing or insufficient, a skilled physician will be able to manage on his own. In terms of physical attributes, Ayurveda states that a physician must have technical expertise, scientific knowledge, and humane understanding to care for the suffering. The physician who employs these qualities with boldness, humility, and judgement can deliver exceptional service while also erecting a durable character edifice for him. He must never forget that his major goals are to be altruistic, to prevent and cure diseases, and to provide relief to those who are suffering. In the case of dying, the physician should be compassionate as defined by Acharya Charaka: with friendship (maître) toward all, compassion for the unwell (Karunya), love and dedication to patients (Sakyepriti), and acceptance of the unavoidable (Upeksanam). ${ }^{17}$

The physician should analyse the disease first, then the drug, and finally the therapy, according to the Charka Samhita. ${ }^{18}$ He should always proceed with the assumption that he knows what he's doing. Even if he is well skilled in drug administration, the physician who begins treatment without knowing the condition succeeds by chance. Unquestionably, a person who understands the characteristics of the disease is wellversed in all therapeutic procedures and is familiar with the correct measures of location and time succeeds. After completing medical school, the physician is almost probably blessed with either Brahma Sattva (Brahma's mental faculty) or Rshisattva (Rishi's mental faculty) (mental faculty of a Risi). Therefore, he is called a "Vaidya" and a Dvija. ${ }^{19}$ 


\section{Modern Perspective}

\section{PROFESSIONAL DUTIES ${ }^{20,21}$}

According to the Supreme Court of India, a person who presents himself as willing to provide medical advice and treatment implicitly agrees that he possesses the necessary expertise and knowledge. 4When consulted by a patient, such a person owes him specific responsibilities, such as a duty of care in selecting what therapy to give or a duty of care in administering such treatment.

1. The treatment of the patient constitutes an implicit contract.

2. Obligation to conduct a thorough examination of the patient with a previous verbal or written agreement.

3. Examination of a female patient with the patient's or relative's agreement in the presence of a female hospital or clinic visitor.

4. It is your responsibility to earn people's trust.

5. The ability to select a patient.

6. It is your responsibility to provide proper instruction or guidance to the patient, both in terms of therapy and disease.

7. Obligation to report communicable diseases

8. Obligation to acquire the patient's consent before attempting surgical treatment, and in the case of minors, the parent's approval.

\section{DUTY TOWARDS COLLEAGUE ${ }^{22}$ :}

1. Treat them with the same respect, honour, and excellent manners that you expect from them.

2. Nothing should be done or said to bring a colleague's name down.

3. Do not try to attract a patient away from a colleague.

4. A free medical service for a co-worker. A breach of any of those duties gives a right of action for negligence to the patient.

\section{NEGLIGENCE OF DOCTOR ${ }^{23}$ :}

It is irresponsible behaviour that has nothing to do with any responsibility to be cautious. A quack treating a patient, for example, is an example of neglect. Negligence is defined as a breach of a legal duty of care. Damage because of the consequences. If the plaintiff establishes that the doctor is negligent but fails to establish loss or damages, he is not entitled to compensation under the Consumer Protection Act.

\section{DUTY TO REFER ANOTHER PHYSICIAN -}

If a patient consults a physician about a sickness that he or she does not have the expertise or knowledge to treat, it is the physician's legal responsibility to notify the patient and propose that the patient see another physician.

\section{DUTY TO GIVE INSTRUCTIONS TO THE PA- TIENT}

In dealing with a case, it is the physician's legal responsibility to provide the patient with all necessary information relevant to the diagnosis, so that the patient has a better understanding of the ailments. As a result, the patient has the right to know the treatment and to seek a second opinion about his treatment, as well as the right to seek alternative forms of treatment if he so desires. The doctor should respect the patient's right to privacy.

\section{RIGHTS AND PRIVILEGES OF PHYSICIANS ${ }^{21}$}

1. Right to select his patient - he has the right to refuse any patient for any reason, but he should not refuse emergency treatment if the patients need it.

2. The right to use his name in the title and description of his qualification.

3. Possession of the right to practise medicine.

4. The ability to provide his patient medicine.

5. Possession and distribution of harmful drugs to his patients.

6. The right to be excused from serving as a juror during an inquest.

7. Right to give evidence in a court of law, as an expert witness.

8. Possession of the authority to issue medical certificates and medico-legal reports.

9. Right to fee recovery - if the patient refuses to pay the reasonable fees, the court can intervene.

10. Right for appointment in public and local hospitals 


\section{DISCUSSION}

The four pillars of treatment in Ayurveda are a physician (Bhishaka), medicament (Dravya), attendant (Upasthata), and patient (Rogi) If this quadruple $(\text { Chatushpada })^{24}$ is provided with traits, it can help to relieve the trouble. This quadruple, which consists of 16 qualities (four of each), is the foundation for treatment success. However, the physician with superior theoretical knowledge, considerable practical experience, dexterity, and cleanliness has the highest place. A physician's qualities also include learning (Vidya), rationality (Vitarka), precise knowledge (Vijnana), memory (Smruti), speed of action (Tatparta), and appropriately treating patients (Kriya). ${ }^{25}$ The fourfold attitude of a physician is described by Charaka as friendliness (Maitri), sympathy toward the diseased (Karunyaarteshu), attachment to the reversible (Shakyasyapriti), and indifference to those who are approaching the end (Upekshanam). ${ }^{26}$ Charaka advises the physician to make every effort to ensure the health of all patients. Even if it means his life, a physician should not think badly of his patients. Even in his mind, he should not approach other people's women or property. This Ayurvedic text's moral concept reflects the idea of western ethics, which holds that the patient should always be seen as a goal, not a means. ${ }^{27}$ While entering a patient's home, the physician should be accompanied by a known person whose admission is approved, with head bowed, good memory, quietness, careful thought, and appropriate movement. After entering, the physician's words, intellect, and senses should be focused solely on the patient's illness and care. He should ignore the rest of the patient's body's entities. $\mathrm{He}$ needs to be respectful of female patients. As a result, according to bioethics principles, one should not enjoy oneself in a patient's home while the patient is ill. In western ethics, the patient's right to autonomy necessitates informed consent and the true disclosure of the patient's medical state. However, Charaka implies that speaking the truth about the condition is not always the best option if doing so could hurt the diseased or others. As a result, whether the physician is telling the truth or not, Ayurveda ethics gives the doctor the upper hand. Ayurveda's underlying precepts are expressed ethically in this way.

- The old medical science's goal Ayurveda - curing diseases and protecting the healthy

- The basic requirements of treatment are a physician, drugs, attendant, and patient, all of whom contribute to a good doctor-patient relationship.

- Physician attitude - friendliness, compassion toward the patient, attachment to the reversible, and indifference to those who are nearing the end Wearing white clothing and adhering to a code of ethics.

- Characteristics of a good physician - He should have superior theoretical and practical knowledge, as well as dexterity and cleanliness. He should also be cautious, humble, devoid of jealousy, truthful, content, vigilant, pure, and right.

- Manner of medical practices -The ailment must first be diagnosed before treatment can be determined. Before examining a female patient, she should give her consent. Always take the initiative when speaking with the patient. While treating a patient, a physician should not brag about himself. Practice is more fruitful when you have a clear mind and a skilful hand.

\section{CONCLUSION}

The physician's above-mentioned responsibilities will help him, or she practise ethically and lawfully. It will aid in the improvement of physician-patient communication in hospitals. Physicians must keep up with changing legal developments and ethical debates.

\section{REFERENCES}

1. Patwardhan K, Gehlot S, Singh G, Rathore HC. Global challenges of graduate-level Ayurvedic education: A survey. Int J Ayurveda Res. 2010; 1:49-54.

2. Francis CM. Medical Ethics. 2nd ed. New Delhi: Jaypee Brothers: Medical Publishers (P) Ltd; 2007. Autonomy and informed consent; p. 54.

3. Tiwari PV. 1st ed. Varanasi, India: Chaukhanbha Visvabharati Publication; 2012. Medical Ethics of Ayurveda. 
4. Charaka samhitā of Agnivesha. Revised by Charaka and supplemented by Dridhabala with Ayurveda Dipika commentary by Chakrapanidata edited by Vaidya Yadavjitrikamaji Acharya, sutra sthana 9/21-23. Chaukhambha Surbharati Prakashana, Varanasi. Reprint2000.pp- 90

5. Astanga Sangarh of Vardha Vagvatta with Indu commentary edited by Vaidhya Anant Damodar Aathwale Sutra Sthan 15/38 Shrimad Atrya publication Pune.

6. Sushruta, Sushruta Samhita, Sutra Sthana, Vishikhanupraveshaniya Adhyaya. Vol. 1. Varanasi: Chaukhamba Orientalia; 2008. 10/3, translated by Prof. Srikantha Murthy KR; p. 61

7. Gautam Biswas, Review of forensic medicine \& toxicology, 4th edition, New Delhi: Jaypee brothers: medical publishers (p) Ltd; 2019. P-1

8. Jaikrishna Ayurveda Series, Charak SamhitaVol.2, Sutrasthana 1/133, Varanasi; Chaukhamba orientalia; 2008.P-28

9. Jaikrishna Ayurveda Series 151, Charak SamhitaVol.2, Sutrasthana 9/23, Varanasi; Chaukhamba orientalia; 2008. P-146

10. K.S.N. Reddy, The Essentials of forensic medicine and toxicology, 32 addition, New Delhi; 2013.p-24 6. Prof K.R. Srikantha Murthy, Sushruta Samhita, Vol.1, Sutrasthana 5/10, Varanasi; Chaukhamba orentalia; 2017. P-30

11. Agnivesha, Charaka, Dridhabala, Charak Samhita, Sutra Sthana, Dirghajivitiya Adhyaya. In: 1/15. Sharma PV, editor. Varanasi: Chaukhambha Orientalia; 2011. p. 4

12. Sushruta, Sushruta Samhita, Chikitsa Sthana, Netrabastipramana Pravibhagachikitsa Adhyaya.35/32, translated by Prof. Srikantha Murthy KR. Vol. 1. Varanasi: Chaukhamba Orientalia; 2008. p. 336.

13. Agnivesha, Charaka, Dridhabala, Charak Samhita, Sutra Sthana, Traisheneya Adhyaya. In:11/3. Sharma PV, editor. Varanasi: Chaukhambha Orientalia; 2011. p. 69

14. Agnivesha, Charaka, Dridhabala, Charak Samhita, Sutra Sthana, Traisheneya Adhyaya. In: 11/3.Sharma PV, editor. Varanasi: Chaukhambha Orientalia; 2011. p. 70

15. Agnivesha, Charaka, Dridhabala, Charak Samhita, Sutra Sthana, Traisheneya Adhyaya. In: 11/3.Sharma PV, editor. Varanasi: Chaukhambha Orientalia; 2011. p. 70

16. Agnivesha, Charaka, Dridhabala, Charak Samhita, Sutra Sthana, Traisheneya Adhyaya. In: 11/3.Sharma
PV, editor. Varanasi: Chaukhambha Orientalia; 2011. p. 71

17. Tiwari PV. 1st ed. Varanasi, India: Chaukhanbha Visvabharati Publication; 2012. Medical Ethics of Ayurveda.

18. Agnivesha, Charaka, Dridhabala, Charak Samhita, Sutra Sthana, Khuddakchatushpada Adhyaya. In: 9/26. Sharma PV, editor. Varanasi: Chaukhambha Orientalia; 2011. p. 64

19. Agnivesha, Charaka, Dridhabala, Charak Samhita, Sutra Sthana, Khuddakchatushpada Adhyaya. In: 9/26. Sharma PV, editor. Varanasi: Chaukhambha Orientalia; 2011. p. 65

20. Gautam Biswas, Review of forensic medicine \& toxicology, 4th edition, New Delhi: Jaypee brothers: medical publishers (p) Ltd; 2019. P-18

21. Gautam Biswas, Review of forensic medicine \& toxicology, 4th edition, New Delhi: Jaypee brothers: medical publishers (p) Ltd; 2019. P-19

22. Medical Ethics. 2nd ed. New Delhi: Jaypee Brothers: Medical Publishers (P) Ltd; 2007. CM Francis. Right to life; p. 70.

23. Medical Ethics.2nd ed. New Delhi: Jaypee Brothers: Medical Publishers (P) Ltd; 2007. CM Francis. Right to life; p. 72

24. Bodh Shanti et al. ETHICS OF PHYSICIAN IN AYURVEDA AND TIBETAN SYSTEM OF MEDICINE "UJAHM 2016, 04 (03): Page 1-7.

25. Bodh Shanti et al. ETHICS OF PHYSICIAN IN AYURVEDA AND TIBETAN SYSTEM OF MEDICINE “UJAHM 2016, 04 (03): Page 1-7.

26. Dr Anita, Dr Parmanand Upadhyay, Dr Sunita Godara, Dr. Gourishankar Rajpurohit Medical Ethics And Legal Duties Of A Doctor In Ancient Time, IRJAY, December: 2020 Vol- 3, Issue-12; 214- 224

27. Tiwari PV. 1st ed. Varanasi, India: Chaukhanbha Visvabharati Publication; 2012. Medical Ethics of Ayurveda.

\section{Source of Support: Nil Conflict of Interest: None Declared}

How to cite this URL: Durga Lal Sharma \& Shri Ram Saini: Rights And Duties Of Physician According To Ayurveda And Modern Perspective. International Ayurvedic Medical Journal \{online\} 2021 \{cited August 2021\} Available from: http://www.iamj.in/posts/images/upload/1789_1794.pdf 